\title{
UZALEŻNIENIE BEHAWIORALNE W PERSPEKTYWIE TEOLOGII MORALNEJ. PREZENTACJA I OCENA
}

\begin{abstract}
Streszczenie
$W$ wysoce rozwiniętych społeczeństwach podkreśla się wolność wyboru. Problemem staje sięjak rozumieć zdolność podejmowania decyzji: czy mój wybór może kierować się w stronę zła. Przejawem konsumpcyjnego życia są uzależnienia nie tylko od substancji psychoaktywnych, ale także od zachowań. Można się uzależnić od wszystkiego. Dlatego ważne jest rozumienie wolności, która się kieruje wartościa-prawdą. Artykuł przedstawia wolność jako wartość dynamiczna, która trzeba zdobywać i umacniać przez cnoty moralne. Jeśli nie ma rozwoju wewnętrznego, to pojawia się podatność na wszelkiego rodzaju uzależnienia. W dalszej części prezentuje się przykłady uzależnień od zachowań, ich geneze, fazy i skutki. Nastepnie autor przedstawia oceny zachowań od strony materii czynu oraz od strony podmiotu. Wuzależnieniu może zachodzić pomniejszenie odpowiedzialności moralnej. Jednakże podkreśla się powinność walki z uzależnieniem. Przywrócona wolność w Chrystusie uwypukla wartość dobrego moralnie życia.
\end{abstract}

Słowa kluczowe: wolność, uzależnienia behawioralne, uzależnienia, cnoty moralne, odpowiedzialność moralna

* Dr Michał Cherubin - teolog, wykładowca teologii moralnej, etyki i bioetyki w Wyższym Seminarium Duchownym w Łomży oraz na Papieskim Wydziale Teologicznym św. Jana Chrzciciela w Warszawie. 
„Liczy się to, aby każdy wierny rozpoznał swoją drogę i wydobył z siebie to, co ma najlepszego, to, co najbardziej osobistego Bóg w nim umieścił (por. 1 Kor 12,7), a nie marnował sił, usiłując naśladować coś, co nie było dla niego pomyślane". Papież Franciszek zachęca współczesnego wierzącego do rozeznania osobistego szlaku do Boga, który powołuje do istnienia oraz towarzyszy swoim dzieciom w Jezusie Chrystusie. To się dokonuje dzięki darowi nadprzyrodzonemu, który wypływa z samego serca Trójcy Przenajświętszej, łasce, będącej w działaniu moralnym pierwszą przyczyną: «Albowiem to Bóg jest w was sprawcą i chcenia, i działania zgodnie z [Jego] wolą» (Flp 2,13).

Jak wyjaśnia teolog Domu Papieskiego, Wojciech Giertych: „Bóg, który jest Stwórcą natury i Dawcą łaski nie działa obok natury, ale wewnątrz niej. Przyjęcie Boga jako swego Pana i swego celu dokonuje się wewnątrz ludzkiego życia, jego faktycznych, społecznych realiów, wewnątrz człowieczej psychiki i naturalnych skłonności. Punktem styku natury jest ludzka dusza, w której zasadza swoją miłość" . Optyka realizacji drogi do szczęśliwości wiecznej zawiera w sobie żywe barwy przeżywanej komunii z Bogiem, a niekiedy cienie ludzkiej nędzy i słabości. Utrata wewnętrznej wolności prowadzi do destrukcji osobowości, relacji międzyludzkich - i w najgorszym przypadku - życia. Rozbity wewnętrznie człowiek wydaje się, że czołga się w błocie nałogu i swoich usprawiedliwień. Momentem zwrotnym człowieka pogrążonego w niewoli uzależnień staje się sytuacja, w której zaczyna modlić się do Boga: «Pozwól mi zrozumieć drogę Twych postanowień, abym rozważał Twe cuda. Moja dusza nie zaznaje spoczynku ze zgryzoty: podźwignij mię zgodnie z Twoim słowem» (Ps. 119 27-28).

Podejmując niniejszy temat, przedstawię zarys koncepcji wolności w ujęciu tomistycznym jako tło kształtowania się dojrzałych postaw moralnych. W dalszej części artykułu scharakteryzuję przykładowe uzależnia behawioralne. Następnie ukażę wpływ ich na odpowiedzialność człowieka oraz ewentualną drogę wychodzenia z nałogu w perspektywie moralnej: łaski i sakramentu pokuty i pojednania, ponieważ „w teologicznej refleksji nad moralnością ważne jest nie tyle opisanie tego co człowiek czyni Bogu, ale opisanie tego co Bóg czyni człowiekowi”’3.

\footnotetext{
1 Franciszek, Gaudete et exsultate. Adhortacja Apostolska o powołaniu do świętości w świecie współczesnym (2018), Wydawnictwo M, Kraków 2018, n. 11.

2 W. Giertych, Jakżyć łaską. Płodność Boża w czynach ludzkich, Bernardinum, Pelplin 2014, s. 27.

3 Tamże, s. 60.
} 


\section{1. «Poznajcie prawdę, prawda was wyzwoli» $(\mathrm{J} 8,32)$ - Wolność do dobra}

Św. Ireneusz podaje cechy człowieczeństwa i podobieństwa Bożego: „Człowiek jest istotą rozumną, a przez to podobną do Boga, został stworzony jako wolny i mający panowanie nad swoimi czynami”" . W tym ujęciu fundatorem i gwarantem ludzkiej wolności staje się Bóg, który «umiłował świat, że Syna swego Jednorodzonego dał, aby każdy, kto w Niego wierzy, nie zginął, ale miał życie wieczne» (J 3,16). W Chrystusie dokonuje się odkupienie każdego człowieka. Tajemnica Paschy zapewnia ufne oczekiwanie chrześcijanina, a zarazem zakłada stałość jego działania moralnego. „Z tożsamości Syna-podkreśla P. Laird - który jest dla Ojca, wynika etyka, która nadaje formę, w najpełniejszym tego słowa znaczeniu, aksjomatowi agere sequitur esse (por. Rz 8,14-21). Duch Święty prowadzi Jezusa Chrystusa, aby był formą wolnej odpowiedzi danej w miłości Ojcu"s. Konsekwencją misterium paschalnego jest udział w wolności Chrystusa, która prowadzi nas do pogłębienia naszej wolności. Jak pojmowana jest ta wolność? W Katechizmie Kościoła Katolickiego czytamy: „Wolność jest zakorzenioną w rozumie i woli władzą działania i niedziałania, czynienia tego lub czegoś innego, a więc podejmowania przez siebie przemyślanych działań"6. Jest to koncepcja wolności opierająca się na tradycji tomistycznej, według której nie jest „dyktatorem władz", ale pewną syntezą rozumu, poszukającego prawdy oraz woli, nastawionej na dobro?. Wolny wybór, więc jest oparty na skłonnościach do poznania prawdy i dobra. Natomiast w myśli W. Ockhama, wolny wybór jest pierwotny w stosunku do rozumu i woli, jest pierwszą zdolnością, a więc obojętną na wartość, ponieważ mogę tak samo wybrać pozostanie przy życiu, jak odebranie je sobie. Wszystkie naturalne skłonności zebrane w skłonności do dobra lub do szczęścia, zostają w ten sposób podporządkowane wyborowi i dowolnemu określeniu woli. Zostają jakby wyrwane z głębi woli i umieszczone przed nią, pod nią, i poddane jej arbitrażowi. Już nie należą do istoty wolności ${ }^{8}$. W ockhamowskim ujęciu wolności nie następuje

4 Św. Ireneusz, Adersus haereses, IV, 4,3, cyt. za: Katechizm Kościoła Katolickiego [potem KKK], Pallottinum, Poznań 2009, n. 1730.

5 P. Laird, Wolność synowska, odpowiedzia w Duchu Świętym na Mitość Ojca, w: Synowie w Synu. Teologia moralna fundamentalna, red. R. Tremblay - S. Zamboni, Promic, Warszawa 2009, s. 215.

6 Katechizm Kościoła Katolickiego, Pallottinum, Poznań 2009, n. 1731.

7 Por. W. Bartkowicz, Wolność jako problem graniczny filozofii i teologii, Wydawnictwo Archidiecezji Warszawskiej, Warszawa 2004, s. 59.

8 Por. S. T. Pinckaers, Źródła moralności chrześcijańskiej, W drodze, Poznań 1994, s. 304. 
zerwanie jedynie ze skłonnościami naturalnymi, ale także następuje usunięcie zmysłowości, która budzi podejrzenie o grzech i zawłaszczanie pola działań, a nie jako dobra przyjaciółka w działaniu sprawnym i roztropnym; zerwanie z ciągłością i celowością, które atomizują konkretne czyny ludzkie na niezależne epizody. „Taka wolność nie potrzebuje rozwoju. [...] Wizja życia ludzkiego i moralności całkowicie się zmienia. W człowieku następują po sobie wolne uczynki, których nie może już głęboko zjednoczyć żaden czynnik, jak dążenie do jakiegoś celu czy nawet poczucie osobowości"’. Także pouczenia moralne i poruszenia łaski, stałyby się ograniczeniem niezdeterminowanej wolnej woli.

W koncepcji wolności św. Tomasza nie dochodzi do atomizacji władz człowieka czy działania obdarowującego Boga, przeciwnie, następuje harmonizacja tego co naturalne wraz z tym co nadprzyrodzone. Łaska Boga uprzedza wszelkie działania ludzkie. Bez krępowania wolności dotyka intelektu i woli człowieka. Wszelkie zdolności naturalne i dary nadprzyrodzone prowadzą do rozwoju wolności. „Wolna wola - stwierdza św. Tomasz - jest przyczyną swojego ruchu, jako że człowiek swoją wolną wolą porusza siebie do działania. Niekoniecznie jednak wolność wymaga tego, żeby być pierwszą przyczyną samego siebie, podobnie jak do tego, żeby być przyczyną drugiego, nie jest wymagane, żeby być jego pierwszą przyczyną. Bóg więc jest pierwszą przyczyną poruszającą zarówno przyczyny naturalne, jak i dobrowolne. [...] bowiem Bóg działa w każdym zgodnie z jego swoistą właściwością"10. W jaki sposób Bóg przekonuje człowieka? Nie jest to zewnętrzny przymus, ale formą przyciągania stają się argumenty racjonalne. Jak wyjaśnia T. Gałuszka, Trójca Przenajświętsza motywuje na trzy sposoby: „Ojciec dotyka urokiem, pozwalając człowiekowi doświadczyć piękna Jego majestatu, mądrości i mocy; Syn pociąga rozpalaniem pragnienia poznawania i kochania prawdy; Duch poprzez wewnętrzne poruszenia i natchnienia"11. Wolność synowska nie orientuje się jedynie w perspektywie odrzucenia grzechu, ale w dynamicznym podążaniu za większym dobrem. Jest opcją bycia „z” i „dla” Ojca i Syna i Ducha Świętego. $\mathrm{Z}$ tak pojętej argumentacji wypływa świadome i wolne działanie ludzkie, oparte na prawdzie, które rośnie codziennością słów: «Jednego ci brakuje. Idź sprzedaj wszystko co masz i rozdaj ubogim, a będziesz miał skarb w niebie» (Mk 10, 21). Przez Chrystusa, z Chrystusem i w Chrystusie, człowiek nabiera tożsamości „bycia-dla-drugiego i zgody-na-bycie-drugiego"'2.

\footnotetext{
9 Tamże, 307.

10 Tomasz z Akwinu, Suma teologiczna, Veritas, Londyn 1963-1980, I-II, q. 83, a. 1.

11 T. Gałuszka, Odnowa w łasce. Teologia charyzmatów św. Tomasza z Akwinu, Esprit, Kraków 2018, 38.

12 P. Laird, Wolność synowska... art. cyt., s. 228.
} 
Odkrywana tożsamość w Synu wyjawia w konkretności działania, które nie może być jedynie epizodyczne, ale wypływa ze stałej dyspozycyjności do dobra cnoty $^{13}$. Zachodzi między wolnością a działaniem swoista korelacja. „Jeśli się z wolności - stwierdza B. Häring - dobrowolnie nie korzysta (zaniedbuje wolność) lub nie korzysta w pełni, to ona marnieje. Jeżeli wolność wyczerpuje się tylko w grzesznym odmawianiu powinności, to stanie się ona stopniowo coraz bardziej bezsilna wobec dobra. Jest to bezsilność prawdziwej wolności w ogóle"14. W braku moralnie dobrego działania dochodzi do abdykacji wolności w Synu. Dochodzi do anarchii w strukturze działania popędów. Zanika wewnętrzna determinacja woli: stawianie sobie określonych celów i konsekwencji ich realizacji. To są znamiona braku wolności ${ }^{15}$. Objawia się niemoc decyzji: „uleganie mocy popędów. Gdyby nawet zło posiadło po swej stronie największą moc popędu, to moc samej wolności jest tak wielka, że może skierować moc popędu ku dobru ${ }^{16}$.

Cnoty kardynalne, pobudzone łaską i sprawnościami wlanymi: roztropność, sprawiedliwość, umiar i męstwo, są podstawą i przestrzenią rozwoju wolności. Roztropność udoskonala umiejętność poznawania i dobierania środków - i co najważniejsze - określenia celu czynności. W działaniu zewnętrznym człowieka i relacji z innymi ludźmi nieodzowna staje się sprawiedliwość: oddać to, co komu się słusznie należy. Z kolei cnota męstwa, bazująca na uczuciach gniewliwych (np. opanowanie lęku), pomaga uzyskaniu dobra trudno osiągalnego. Ostania cnota - umiarkowania, związana z uczuciami pożądliwymi (np. przyjemność, radość) organizuje odpowiedni porządek w zakresie rozumnego przeżywania przyjemności ${ }^{17}$.

Rezygnacja w twórczej wolności do dobra, opartej na cnotach życia moralnego, staje się dramatem zatracania podobieństwa do Boga. Nie każdy upadek człowieka kończy się utratą dyspozycji do dobra. Niestety przez regularność wyborów może nastąpić utrwalenie moralnie złych postaw lub może dojść do swoistego błędu rozumu wobec właściwego dobra (bonum universale) ${ }^{18}$. Jeśli działanie woli skoncentruje się jedynie na realizacji dobra partykularnego (bonum particulare), to przeobraża się w złotego cielca (Por. Wj 32, 4), który żąda codziennych ofiar

13 Św. Tomasz, idąc śladem św. Augustyna, podaje: „dobrej jakości umysłu, dzięki której w sposób prawy się żyje, którą nikt źle się nie posługuje i którą Bóg w nas bez nas sprawia [...]". Tomasz z Akwinu, Suma teologiczna, I-II, q. 55, a. 4.

14 B. Häring, Nauka Chrystusa. Teologia Moralna. t. I, Pallottium, Poznań 1962, 43.

15 Por. S. T. Pinckaers, Źródła moralności ... dz. cyt., s. 362.

16 B. Häring, Nauka Chrystusa... dz. cyt., s. 124.

17 Por. A. Borowski, Teologia moralna, t. I, KUL, Lublin 1960, s. 247-248.

18 W. Bartkowicz, Wolność jako problem... dz. cyt., s. 59. 
(działań) - w konsekwencji - zabiera wolność w Synu. Staje się przyczyną do powstania trwałej sprawności do czynienia zła, którą określa się mianem wady. W niej zachodzi nieuporządkowane pożądanie dobra cząstkowego ${ }^{19}$. Jak wyjaśnia ojciec J. Woroniecki, można wyróżnić trzy stopnie procesu powstawania wady:

- pierwszy, skłonność wrodzona lub nieświadomie nabyta i rozwinięta, za którą nie ponosi się odpowiedzialności;

- drugi etap, pewne, ćwierć-wady, pót-wady, zawiera w sobie targowanie się ze złem, hamuje przy tym wzrost cnót;

- trzeci etap, trwałość zachowania, człowiek przy każdej okazji decyduje się na realizację moralnego zła - dochodzi do wady formalnej ${ }^{20}$. Jednakże św. Tomasz podkreśla, że wada nie może zmniejszyć skłonności do dobra ze względy na jej źródło: natura ludzka. Przeciwnym razie, nastąpiłoby zniszczenie dobra rozumnej natury. Pojedyncze grzechy, wada stawiają przeszkodę do osiągniecia celu, „sprzeciwiają się porządkowi rozumu ludzkiego, sprzeciwiają się także prawu wiecznemu"²1.

\section{2. «Czynie czego nie chcę» $(\operatorname{Rz} 7,16)$ - przykłady uzależnień behawioralnych}

Perspektywa wolności w Synu zakorzeniona jest wolności od. Jeśli nie ma wolności wewnętrznej, która przejawia się nie tylko w unikaniu zła, ale także w rozumnym używaniu dobra partykularnego (rozrywka, zakupy). Koncepcja wolności bez wartości: może stać się pewną fikcją wolności. Współczesny człowiek, szukający wrażeń, uciekający od smutku i przykrości, nie szuka pocieszenia jedynie w substancjach psychoaktywnych (alkohol, narkotyki), ale także wykonywaniu pewnych działań: seks, zakupy, gry on-line, które przynoszą chwilową ulgę czy namiastkę szczęścia. Według badań CBOS-u (Centrum Badania Opinii Społecznej) wykazuje się, że 4\% Polaków ma poważny problem z hazardem, a 3-6\% populacji Amerykanów wykazuje oznaki występowania seksoholizmu ( $\mathrm{PH}$ - patologia hiperseksualizmu). Rozwój nowych środków komunikacji cybernetycznej przyniósł syndrom „uwikłania się w sieć”: około 6\% młodzieży w Grecji przejawia uzależnianie od Internetu ${ }^{22}$. Uzależnienia behawioralne (behavioral

19 Tomasz z Akwinu, Suma teologiczna, I-II, q. 84, a. 4.

20 Por. J. Woroniecki, Katolicka etyka wychowawcza, t. I, KUL, Lublin 1986, s. 388-389.

21 Tomasz z Akwinu, Suma teologiczna, I-II, q. 71, a. 2.

22 Por. B. T. Woronowicz, Uzależnienia behawioralne, ze szczególnym uwzględnieniem patologicznego hazardu oraz uzależnienia od komputera i sieci, w: Zniewoleni działaniem 
addictions ${ }^{23}$ ) określa się jako „formy zaburzeń (nałogów) nie związanych z przyjmowaniem substancji psychoaktywnych, a z niekontrolowanym wykonywaniem pewnych czynności"24. Do diagnostyki używa się następujących wskaźników: zaabsorbowanie - dana czynność dominuje nad innymi działaniami; modyfikacja nastroju - działanie zmienia nastrój; tolerancja - zwiększa się zapotrzebowanie na działanie; symptomy odstawienne - fizyczna i psychiczna przykrość z braku danej czynności; konflikt na płaszczyźnie interpersonalnej i intra-psychicznej; nawrót, czyli po okresie abstynencji powrót do schematu danego zachowania. Czynności od których można się uzależnić, należą do zakresu codzienności czy rodziny (zakupy, jedzenie, praca, seks). Momentem newralgicznym jest stopień powtarzalności - fiksacji ${ }^{25}$. Głównym podłożem warunkującym uzależnienia behawioralne są czynniki biologiczno-genetyczne: w określonych warunkach może nastąpić aktywacja określonego genu; układ nagrody i neuroprzekaźniki (dopamina i serotonina); czynniki psychologiczno-społeczne: np. deficyty, niska samoocena, trudności w nawiązywaniu relacji społecznych; brak radzenia sobie z problemami, brak świadomości swoich emocji, nieumiejętność radzenia sobie ze stresem ${ }^{26}$. Etiologia uzależnień behawioralnych jest różnorodna podobnie jak w uzależnieniach od substancji psychoaktywnych ${ }^{27}$. Różnica między uzależnieniami polega na pochodzeniu źródła satysfakcji zaspokojenia. M. Rowicka, autorka książki „Uzależnienia behawioralne. Terapia i Profilaktyka”, wyjaśnia „przedmiotem uzależnienia $\mathrm{w}$ przypadku uzależnień od substancji jest to substancja przyjmowana z zewnątrz, natomiast $\mathrm{w}$ przypadku uzależnień behawioralnych jest to zachowanie, które najczęściej stanowi składową zdrowego funkcjonowania człowieka" ${ }^{28}$. Niekiedy uzależnienia behawioralne są sprzężone z uzależnieniami

uzależnienia behawioralne a rodzina, red. P. Morciniec, Wydział Teologiczny Uniwersytetu Opolskiego, Opole 2013, s. 31.

23 Istnieją dwa terminy, które określają uzależnienie: „Termin dependence oznacza uzależnienie od substancji fizycznej i chemicznej, sytuację, w której organizm domaga się określonej substancji aby mógł funkcjonować. Addiction to uzależnienie psychologiczne, zmuszające do poszukiwania przedmiotu, bez którego egzystencja traci swój sens". C. Guerreschi, Nowe uzależnienia, Wydawnictwo Salwator, Kraków 2006, s. 37.

24 M. Rowicka, Uzależnienia behawioralne. Terapia i Profilaktyka, Fundacja Praesterno, Warszawa 2015, s. 6.

25 Tamże, s. 8.

26 Tamże, s. 11-17.

27 Cz. Cekiera, Z badań nad etiologia i motywacją uzależnień (narkomania, lekomania, alkoholizm, nikotynizm), w: Problemy współczesnej psychologii, red. Z. Zalewski, Polskie Towarzystwo Psychologiczne, Lublin 1992, s. 588.

28 M. Rowicka, Uzależnienia behawioralne... dz. cyt., s. 8. 
od substancji. Klasycznymi przykładami uzależnień są: zakupoholizm; internetoholizm; seksoholizm, pracoholizm oraz hazard patologiczny.

Zakupoholizm wiąże się z pewną kompulsywnością, która szuka rozładowania złego samopoczucia. Obsesyjny neurotyk przeciwdziała „swym przeraźliwym myślom przez specyficzne działania"29. Poczucie pustki egzystencjalnej przynagla do działania w celu jej „,wypełnienia”. Jest tylko iluzoryczna czynność, gdyż przykre poczucie psychiczne powraca. Niekiedy uzależnienie od zakupów ogniskuje się w kategorii zaburzeń impulsywności, ponieważ związane jest z przyjemnością ${ }^{30}$. W „łowieniu okazji”, w kolekcjonowaniu rzeczy można wyróżnić cztery fazy: przewidywanie, przygotowanie, ekscytacja i refleksja nad wydatkami (poczucie winy) ${ }^{31}$.

Kolejnym zachowaniem związanym z prozą życia i pracą może być uzależnienie od środków wirtualnej komunikacji. „Termin wirtualny - jak zauważa C. Guerreschi - pochodzi od łacińskiego słowa virtus, oznaczającego siłę, moc [...]”32. W czasach współczesnych Internet stał się narzędziem pracy, źródłem informacji, poznawania nowych osób czy też rozrywki. Wśród typów nałogowych zachowań możemy wyróżnić: uzależnienie od informacji (information addiction). Objawia się długotrwałym szukaniem i zbieraniem nowych danych. Konsekwencją jest: brak troski o najbliższych, zmęczenie, spadek produktywności i efektywności pracy. Kolejną aktywnością związaną z wirtualnym światem jest korzystanie z materiałów pornograficznych w sieci (Internet pornography addiction). Zachowanie dotyczy oglądania zdjęć i filmów związanych z intymną sferą człowieka, przez co wyklucza się międzyosobowe przeżywanie ludzkiej seksualności. Maniakalne korzystanie z pornografii ma destruktywny wpływ na pojmowanie ludzkiego ciała jako przedmiotu oraz na przeżywanie aktywności seksualnej w życiu realnym: może powodować rozbudzenie popędu seksualnego - hiperseksualność lub oziębłość seksualną.

Kolejnym zachowaniem, które może powodować uzależnienie, są gry komputerowe w sieci (online gaming addiction): np. World of Tanks. W zachowaniu nałogowym wszelki potencjał człowieka: pomysłowość, inteligencja, czas są absorbowane w przeżywaniu rozgrywki wirtualnej. Tworzą się wirtualne klany - drużyny, grające w określonym czasie i rozgrywce. Podobnie dzieje się w socjomanii internetowej (Internet social interaction), gdzie następuje przewartościowanie relacji międzyludzkich, ważniejsze stają się znajomości wirtualne nad kontaktami $\mathrm{w}$ realu. Takie zachowanie może być jednym z etapów romansów w sieci (online

\footnotetext{
29 A. P. Sperling, Psychologia, Zysk i Sk-a, Poznań 1995, s. 321.

30 C. Guerreschi, Nowe uzależnienia... dz. cyt., s. 227.

31 Por. B. T. Woronowicz, Uzależnienia behawioralne... art. cyt., s. 43.

32 C. Guerreschi, Nowe uzaleznienia... dz. cyt., s. 32.
} 
affairs), które mogą zniszczyć niejedno małżeństwo. Staje się alternatywną rzeczywistości, w której powierza się czas i intymne sekrety i pragnienia ${ }^{33}$. Występują także uzależnienia: od zakupów w sieci (online shoopping addiction34) oraz od hazardu (online gambling addiction) ${ }^{35}$. W przypadku dwóch ostatnich uzależnień sieć wirtualna staje się ułatwieniem realizacji zachowań nałogowych.

W gamie zachowań ludzkich może pojawić uzależnienie od seksu (sex addiction). Na wstępie należy znaczyć, że „zdrowy erotyzm - jak przypomina papież Franciszek w adhortacji Amoris laetitia - chociaż byłby złączony z poszukiwaniem przyjemności, zakłada podziw, a zatem może uczłowieczyć impulsy"36. Przeżywanie aktywności seksualnej ma zazwyczaj naturę społeczną: prokreacja, szacunek wobec drugiej osoby, zachowanie określonej aksjologii i norm religijnych i obyczajowych.

Oprócz funkcji prokreacyjnej i tworzenia relacji bliskości między kobietą a mężczyzną zachowaniom seksualnym współtowarzyszą także symptomy biologiczno-fizyczne: homeostaza organizmu czy także rozładowanie napięcia seksualnego. W działaniu człowieka może nastąpić koncentracja na neurochemii seksu. Jak zauważa W. Mitoraj, który zajmuje się doradztwem psychologicznym oraz uzależnieniami: „Pozornie seksualne, zachowania apetytywne stają się tu w rzeczywistości sposobem na monotonię, nudę, ospałość, natomiast zachowania konsumacyjne pozwalają odreagować stres, frustrację, oderwać się od sytuacji trudnych, zredukować niepokój, złość, poradzić sobie z bezsennością" ${ }^{37}$. Uzależnienie od seksu, bazujące na wypaczonej relacji z przedmiotami lub osobami, wpływa negatywnie na samopoczucie człowieka. Następuje oddalenie się od obowiązków dnia codziennego i życia rodzinnego. T. Cantelmi, włoski psychiatra definiuje uzależnienie od seksu jako chory stosunek do seksu, który dla jednostki jest środkiem do pozbycia się stresu, ucieczki od nieprzyjemnych uczuć i bliskich relacji, z jakimi sobie nie radzi. Stosunek seksualny staje się podstawową potrzebą, której zaspokojenie uzależniony przedkłada ponad wszystko inne, włącznie z osobami, które traktuje

33 Por. P. T. Nowakowski, Uzależnienie od mediów, w: „Cywilizacja” 2009, nr 28, s. $151-152$.

34 Por. H. L. Lo, N. Harvey, Effects of shopping addiction on consumer decision-making: Web-based studies in real time, ,Journal of Behavioral Addictions” 2012, nr 1, s. 167-70.

35 Por. S. M. Gainsbury, Online Gambling Addiction: the Relationship Between Internet Gambling and Disordered Gambling, „Current Addiction Reports” 2015, nr 2, s. 185-193.

36 Franciszek, Amoris laetitia. Adhortacja apostolska o miłości w rodzinie (2016), Święty Paweł, Częstochowa 2016, n. 150.

37 W. Mitoraj, Zachowania o charakterze seksualnym, w: Zniewoleni działaniem uzależnienia behawioralne a rodzina, red. P. Morciniec, Wydział Teologiczny Uniwersytetu Opolskiego, Opole 2013, s. 67. 
przedmiotowo ${ }^{38}$. Niektóre zachowania mogą prowadzić do czynów karalnych przez prawo: do pedofilii czy gwałtów ${ }^{39}$.

Do uzależnień behawioralnych związanych z życiem codziennym zalicza się pracoholizm. „Praca - stwierdzi ks. J. Tischner, polski filozof, w „Etyce solidarności" - to rozmowa w służbie życia"40. W każdej wspólnocie rodzinnej czy eklezjalnej pracowitość uważana jest za cnotę godną naśladowania, która przynosi uznanie i korzyści materialne. Według definicji W. E. Oatesa, amerykański psycholog: ,,pracoholik to osoba, której potrzeba pracy jest tak wielka, że zaspokajanie jej wywołuje znaczne dolegliwości i wywiera negatywny wpływ na stan zdrowia, osobiste szczęście, relacje międzyosobowe i społeczne" ${ }^{\text {"’l1 }}$. W pracoholizmie dochodzi do utraty kontroli nad zachowaniem balansu między obowiązkami a wypoczynkiem ${ }^{42}$. Relacje międzyludzkie w pracy są negatywne. Między pracownikami często dochodzi do niezdrowej rywalizacji: szkodzenie sobie nawzajem; poniżanie i podkreślanie najmniejszych niepowodzeń. Niejednokrotnie uzależnieniu od pracy współtowarzyszą inne zachowania nałogowe: alkoholizmowi czy zakupoholizmowi ${ }^{43}$.

38 Por. C. Guerreschi, Nowe uzależnienia... dz. cyt., s. 160.

39 Por. C. Rosso, M. Garombo, S. Sanzovo, A. Contarino, P. M. Furlan, Il trattamento clinico degli aggressori sessuali: roflessione sulle criticitá e sugli obiettivi, w: Sessualita e dipendenze; dal desiderio alla violenza. Evoluzione e trattamento, red. F. Avenia, A. Pistuddi, Franco Angeli, Milano 2012, s. 244-246.

40 J. Tischner, Etyka solidarności, Znak, Kraków 2005, s. 25.

41 C. Guerreschi, Nowe uzależnienia... dz. cyt., s. 122.

42 Do zachowań pracoholizmu można odnieść następujące kryteria: „1. silna potrzeba lub poczucie przymusu wykonywania czynności związanych z pracą zawodową; 2. subiektywne przekonanie o mniejszych możliwościach kontrolowania swoich zachowań związanych z pracą; 3. występowanie, przy próbach przerwania lub ograniczenia pracy, stanów niepokoju, rozdrażnienia czy gorszego samopoczucia oraz ustępowanie tych stanów z chwilą powrotu do wykonywania zadań zawodowych; 4. spędzanie coraz większej ilości czasu w pracy w celu zredukowania niepokoju, osiągnięcia zadowolenia czy dobrego samopoczucia, które poprzednio uzyskiwane były w normalnym czasie pracy; 5. postępujące zaniedbywanie alternatywnych źródeł przyjemności lub dotychczasowych zainteresowań na rzecz wykonywania obowiązków zawodowych; 6. wykonywanie czynności zawodowych pomimo szkodliwych następstw (fizycznych, psychicznych i społecznych), o których wiadomo, że mają związek z poświęcaniem dużej ilości czasu na pracę". M. Rowicka, Uzależnienia behawioralne... dz. cyt., s. 51-52.

43 Por. J. Suchy, Pracoholik w rodzinie - korzyści czy zagrożenie?, w: Zniewoleni działaniem uzależnienia behawioralne a rodzina, red. P. Morciniec, Wydział Teologiczny Uniwersytetu Opolskiego, Opole 2013, s. 143. 
Kolejną trudnością społeczną jest nałogowe granie, które wiąże się z marzeniem o wygranej. Hazard, czyli ,wszelkie gry pieniężne, w których o wygranej w mniejszym lub większym stopniu, decyduje przypadek"44. 18 maja 2013 r. Amerykańskie Towarzystwo Psychiatryczne w DSM-V (Diagnostic and Statistical Manual of Mental Disorders) dokonało modyfikacji nazewnictwa z uzależnienia od hazardu (gambling addiction) na zaburzenie hazardu (gambling disorder). Zmiana klasyfikacji oznacza traktowanie nałogu hazardu jako zaburzenie, czyli „utrudnienia funkcjonowania psychicznego lub społecznego jednostki, noszącego znamiona cierpienia i zlokalizowanego wokół objawu osiowego. Zaburzenia posiadają określoną etiologię, patogenezę, dynamikę oraz specyficzne symptomy" ${ }^{\prime 45}$. Zakłada się, że od $0,5 \%$ do 5\% populacji ludności to gracze, którzy nie mają kontroli nad hazardem - dysfunkcje zachowania, które zalicza się do podkategorii, w której znajdują się takie zaburzenia: jak kleptomania - potrzeba kradzieży; piromania przymus podpalania; oraz trychotylomania - kompulsywne wyrywanie włosów ${ }^{46}$.

A. Blaszczynski i L. Nower, specjaliści psychologii behawioralnej, wyróżniają trzy drogi prowadzące do ryzykownych zachowań w zakresie hazardu: 1. behawioralna (behaviorally conditioned problem gamblers), zachowanie nabyte na drodze warunkowania; nie stwierdza się czynników psychopatologicznych, nałogowe zachowanie rozpoczyna się w późniejszych latach życia; w terapii osoby, mając silną motywację, dobrze rokują na przyszłość; 2. emocjonalna (emotionally vulnerable problem gamblers), podłożem zachowań patologicznych jest pochodzenie z rodzin dysfunkcyjnych: niska odporność na stres, silne lęki i stany depresyjne; granie staje się ,ucieczką do raju” przed problemami związanymi z emocjonalnością; 3. impulsywna (antisocial impulsivist problem gamblers), dotyczy osób z zachowaniem antyspołecznym, objawami ADHD, z problemami neuropsychologicznymi, używające substancji psychoaktywnych; w tej grupie rokowania są złe; terapia często musi być wspierana farmakologicznie ${ }^{47}$.

Rdzeniem zaburzenia uprawiania hazardu jest zniekształcenie w sferze poznawczej. Jak podaje M. Rowicka: „Do mechanizmów podtrzymujących uzależnienie od hazardu (zaburzenie uprawiania hazardu) należy szereg błędów poznawczych, mechanizmy zaprzeczenia i iluzji, rozproszenia ja, ale także nałogowego regulowania

44 B. T. Woronowicz, Uzależnienia behawioralne... art. cyt., s. 32.

45 D. Krok, Uzależnienia behawioralne a zmiana jakości życia w perspektywie kontrowersji nad DSM-V, w: Zniewoleni działaniem uzależnienia behawioralne a rodzina, red. P. Morciniec, Wydział Teologiczny Uniwersytetu Opolskiego, Opole 2013, s. 16.

46 M. Rowicka, Uzależnienia behawioralne... dz. cyt., s. 20.

47 A. Blaszczynski, L. Nower, A pathways model of problem and pathological gambling, „Addiction” 2002, nr 92, s. 492-495. 
uczué"48. Osoba z problemem hazardu traktuje przegraną jako prawie wygraną stwierdzona reakcja półkul mózgowych. W celu wygranej - pozyskanie przychylność losu - stosuje się irracjonalne środki gesty (chuchanie) i znaki religijne (znak krzyża). Osoby zaburzeniem od hazardu nie widzą często pogarszającej się sytuacji rodzinnej i finansowej ${ }^{49}$.

\section{3. «Wszystko mogę w Tym, który mnie umacnia» (Flp 4,13) - droga nadziei}

W kontekście przykrych konsekwencji moralnych uzależnień behawioralnych powstaje pytanie natury teologicznej: Czy realizm bólu zła uzależnienia nie przekrzykuje dobroci, prawdy i piękna stworzenia? Czy nie pojawia świadomość marnowania daru dokonywania wyboru? Czy nie pojawia się pewien żal z faktu stworzenia? «Pan widział, że wielka jest niegodziwość ludzi na ziemi i że usposobienie ich jest wciąż złe, żałował, że stworzył ludzi na ziemi, i zasmucił się» (Rdz 6,5). Osoby uzależnione od czynności czy też mające zaburzenie od hazardu przejawiają utratę wolności na poziomie działania. W nałogu rozgrywa się dramat utraty piękna wyborów i postępuje ciągła erozja natury ludzkiej. Od samego początku Pismo Święte podkreśla dobroć ontologiczną stworzenia człowieka: «A Bóg widział, że wszystko, co uczynił, było bardzo dobre» (Rdz 1,31), ale opisuje także upadek pierwszego człowieka - grzech pierworodny, który polegał na nieposłuszeństwu przykazaniu Bożemu ${ }^{50}$. Zło wyboru pierwszych ludzi dotknęło nie tylko relacji między Bogiem a człowiekiem czy między ludźmi, ale także zraniło wnętrze człowieka, jego ciało i duszę: «Jestem bowiem świadom, że we mnie, to jest w moim ciele, nie mieszka dobro; bo łatwo przychodzi mi chcieć tego, co dobre, ale wykonać - nie» (Rz 7,18). Jednakże natura ludzka nie została zniszczona, zachowała swoją integralną substancjalnośćs1. Grzech „nie ukradł” nam ikoniczności Boga w nas, ale ją przysłonił. Każdy człowiek nosi w sobie nieodwołalną obietnicę zbawienia: «Bóg nie posłał swego Syna na świat po to, aby świat potępił, ale po to, by świat został przez Niego zbawiony» $(\mathrm{J} 3,17)$.

48 M. Rowicka, Uzależnienia behawioralne... dz. cyt., s. 27.

49 B. T. Woronowicz, Uzależnienia behawioralne... art. cyt., s. 35.

50 KKK, n. 397.

51 Por. L.F. Ladaria, Wprowadzenie do antropologii teologicznej, WAM, Kraków 1997, s. 88 . 
Dobroć stworzenia zranionej natury i prawda o odkupieniu człowieka przez Chrystusa są fundamentem spojrzenia na problem uzależnień od czynności ${ }^{52}$. Proces wychodzenia „z krainy uzależnienia” wymaga wytrwałości i konsekwencji. Refleksja teologii moralnej patrzy na dwie podstawowe płaszczyzny: pierwsza przedmiot działania; druga - podmiot działania.

Od strony przedmiotowej w uzależnieniach behawioralnych mamy do czynienia z działaniami związanymi z egzystencją człowieka, ale przejawiające się w nadmiarze danego działania. Rzeczywistość o wiele bogatszą - przeżywanie seksualności - redukuje się jedynie do wymiaru przyjemności lub rozładowania pewnego napięcia, pomijając przy tym aspekt prokreacyjny i jednoczący miłość małżonków ${ }^{53}$. Długi czas uzależnienia może powodować działania moralnie złe: np. kłamstwa, kradzież i przemoc słowną wykorzystanie seksualne czy rozbicie rodzin. Uzależnienia behawioralne od strony duchowej można nazwać chorobami duszy ${ }^{54}$.

Od strony podmiotu sytuacja jest bardziej złożona. W teologii moralnej powtarzanie tych samych zachowań moralnie złych wchodzi w zakres nałogu, który jest silną i szkodliwą wadą ${ }^{55}$. Jednak należy odróżniać osoby z pewnymi wadami od osób uzależnionych od czegokolwiek. W pierwszym przypadku mamy do czynienia uleganiem słabości i może zmienić sposób postępowania po zastosowaniu środków naturalnych i wsparciu sakramentami. W drugim przypadku problem jest o wiele głębiej zakorzeniony w człowieku ${ }^{56}$. Warunkami do zaistnienia grzechu śmiertelnego - prócz ciężkiej materii - są pełna świadomość oraz dobrowolnośćc ${ }^{57}$. Pojedynczy grzech jednakże nie powoduje zaistnienia nałogu, choć może do niego

52 W Katechizmie Kościoła Katolickiego nie znajdziemy o hasła uzależnienia behawioralne, jedynie znajdują się gatunkowe określenia uzależnienia - narkomania. Por. KKK, n. 2211,

53 Uzależnienie od seksu jest nad użyciem instynktu płciowego i często wykracza często poza wspólnotę małżonków. Por. S. Witek, Duszpasterstwo w konfesjonale, Pallottinum, Poznań 1988, s. 167. Kongregacja Nauki Wiary, Persona Humana. Deklaracja o niektórych zagadnieniach etyki seksualnej (1975), w: W trosce o życie. Wybrane Dokumenty Kościoła Stolicy Apostolskiej, red. K. Szczygieł, Biblos, Tarnów 1998, n. 7.

54 Jak zauważa patrolog D. Tessore: „Nawykowe pożądanie pieniędzy, seksu, jak i napady złości to również prawdziwe choroby. Ich wpływ na ustrój psychofizyczny niewiele różni się od wpływu twardych narkotyków". D. Tessore, 7 grzechów głównych, Promic, Warszawa 2012, s. 12.

55 Por. J. Woroniecki, Katolicka etyka wychowawcza. t. I, KUL, Lublin 1986, s. 388.

56 Por. M. A. Fuentes, Rivestitevi di sentimenti di misericordia, Edivi, Roma 2014, S. 165.

57 A. Kokoszka, Teologia moralna fundamentalna, Biblos, Tarnów 1998, s. 163. 
prowadzićs ${ }^{58}$. Sprawności moralnie dobre mają pewną trwałość - siłę wewnętrzną, a zanik cnoty odbywa stopniowo i powolnie ${ }^{59}$. W nałogu osoba widzi swoiste dobro, które z realizować, jednakże wszelkie inne racje, które ograniczają działanie uzależniające: zdrowie fizyczne i psychiczne, stabilność finansowa, są zaciemnione. Dominują uczucia pożądawcze, które skupiają się na przyjemności ${ }^{60}$. Jeśli następuje zwalczanie uczuć lub ucieczka od uczuć przykrości, które są także częścią egzystencji człowieka ,to rozpoczyna się proces utraty wolności wewnętrznej ${ }^{61}$. Nie podjęta próba konfrontacji z nałogiem jest naznaczona odpowiedzialnością, choćby habitualnie ${ }^{62}$.

Według tomistycznej teologii moralnej nałogowiec grzeszy wyłącznie pod wpływem złej woli, wola nie stawia oporu złu i nie odczuwa żadnych wyrzutów sumienia po zaistnieniu grzechu ${ }^{63}$. $Z$ drugiej strony pojawienie się realnych oznak walki ze słabością może zmniejszyć złość moralną nałogu ${ }^{64}$. „Mały krok - przypomina papież Franciszek - pośród wielkich ludzkich ograniczeń, może bardziej podobać się Bogu niż poprawne na zewnątrz życie człowieka spędzającego dni bez stawiania czoła poważnym trudnościom" ${ }^{\text {. }}$. Wina subiektywna - pomimo obiektywnego zła - może zostać pomniejszona z powodu ograniczenia świa-

58 Pojedynczy grzech może być przyczyną sprawczą innych grzechów tej samej materii - usposobienie do czynów podobnych. Por. A. Borowski, Teologia moralna.t. I, KUL, Lublin 1960, s. 364.

59 Tamże, s. 213.

60 W teologii moralnej uczucia klasyfikujemy na dwie główne kategorie: pożądliwe związane z przeżywaniem obecnego dobra lub zła: np. zadowolenie, przyjemność, rozkosz, odraza, przykrość, smutek; uczucia bojowe budzą wobec dobra jeszcze nieobecnego lub nadchodzącego zła: otucha, odwaga, strach, lęk, trwoga czy gniew. Por. J. Woroniecki, Katolicka etyka wychowawcza... dz. cyt., s. 158-159.

${ }_{61}$ Por. W. Giertych, Fides et passio, Bernardinum, Pelplin 2015, s. 90.

62 „Nie oznacza - zauważa W. Giertych - to jednak, że prawie mechaniczne złe nawyki są niewolne. Jest w nich zadziałanie wolnego wyboru, który bagatelizuje antywartość danego wyboru i zatrzymuje się na pozornym dobru, nawet jeżeli w momencie decyzji nie było długiej refleksji. Za powtarzające się grzechy, w tym nałogowe, ponosi się pełną moralną odpowiedzialność, gdyż dokonuje się w nich choćby habitualne przyzwolenie na grzech”. W. Giertych, Jak żyć taską... dz. cyt., s. 73-74.

63 Należy odróżnić grzech z nałogu - długie trwanie w złym usposobieniu, od grzechu ze słabości - czynnik wywołujący pochodzi zewnątrz, istnieje pewien opór. Por. A. Borowski, Teologia moralna... dz. cyt., s. 371-373.

64 B. Häring, Nauka Chrystusa... dz. cyt., s. 133.

65 Franciszek, Evangelii gaudium. Adhortacja apostolska o głoszeniu Ewangelii w dzisiejszym świecie (2013), Wydawnictwo M, Kraków 2013, n. 44. 
domości i wolności człowieka ${ }^{66}$. „Uzależnienia behawioralne - zauważa ks. K. Glombik, opolski moralista - ograniczają wolę człowieka, co powoduje, że jego odpowiedzialność zostaje ograniczona, ale głównie w obszarze działań, których ono dotyczy, a nie postępowania człowieka w ogóle"67. Świadomość ludzka zachowuje swoją zdolność rozumowania: dostrzeżenie strat, pogorszenie się zdrowia, sytuacji finansowej, może stać się motywem cierpienia lub złości na zaistniało sytuację człowieka ${ }^{68}$.

W terapii przełomowym momentem staje się uznanie słabości, przyznanie się do braku kontroli nad własnym życiem - od strony teologicznej - jest wynikiem działania łaski w człowieku, która uprzedza dobre decyzje i działanie człowieka. Uznanie słabości i żal serca są znakami nawrócenia. Musi nastąpić swoista naprawa wolności. B. Häring, niemiecki teolog, zauważa: „Złe przyzwyczajenie, jako skutek wielu wolnych decyzji, dopóty zawiera ciężar i wagę poprzednich wolnych decyzji (to znaczy tkwi we wszelkich ich przejawach), dopóki nie zostanie gruntownie odwołane" ${ }^{\prime 9}$. To odwołanie nałogu nie będzie odbywało się na zasadzie abstynencji np. brak zakupów czy aktywności wirtualnej, ale na integracji wewnętrznych władz człowieka oraz określenia granic rzeczywistych potrzeb ${ }^{70}$.

Dążeniem cnoty umiaru w sferze seksualnej w obrębie małżeństwa nie będzie pozbawienie się przyjemności, ale właściwe jej czerpanie ${ }^{71}$. W przypadku osób uzależnionych od pornografii czy też z zaburzeniami od hazardu celem będzie całkowita abstynencja od działania. Środkiem będzie terapia, której poznaje się

66 W przypadku zaburzenia od hazardu, które jest poważniejsze od uzależnień od czynności, może nie zaistnieć wina moralna z powodu habitualnych ograniczeń człowiekaczynnik psychiczny. Por. KKK, n. 1735.

67 K. Glombik, Złożoność problemu odpowiedzialności w sytuacji uzależnienia człowieka, w: Zniewoleni działaniem uzależnienia behawioralne a rodzina, red. P. Morciniec, Wydział Teologiczny Uniwersytetu Opolskiego, Opole 2013, s. 194.

68 Por. W. Giertych, Fides et passio... dz. cyt., s. 42.

69 B. Häring, Nauka Chrystusa... dz. cyt., s. 133.

70 Jak stwierdza W. Giertych: „,nota kontroluje nie samo doświadczenie przyjemności, które jest naturalne, pociągające, zależne w swej sile od dyspozycji cielesnej i psychicznej danej osoby i w pełni dopuszczalne, a jedynie przyleganie do niej, czyli chodzi o to, aby nie uczyniono sobie z niej wartości ponad miarę, która by przesłaniała inne, ważniejsze sprawy" W. Giertych, Fides et passio... dz. cyt., s. 135.

71 We wspólnocie małżeńskiej właściwe korzystanie przyjemności seksualnej będzie respektowanie cykliczności właściwą funkcjom rozrodczym. Antykoncepcja może powodować utrwalenie się zachowań nałogowych. Por. Paweł VI, Encyklika Humanae Vitae (1968), w: W trosce o życie. Wybrane Dokumenty Kościoła Stolicy Apostolskiej, red. K. Szczygieł, Biblos, Tarnów 1998, n. 17. 
i mechanizmy potrzeb i uczuć, następuje ich integracja oraz pogłębione życie duchowe, które otwiera na rzeczywistość nadprzyrodzoną: «Wszystko mogę w Tym, który mnie umacnia» (Flp 4,13). Nieodzowną pomocą staje się sakrament pokuty i pojednania, w którym następuje przebaczenie grzechu. Integralność sakramentu potrzebuje decyzji o zerwaniu z grzechem - uzależnieniem. Wybór drogi nawrócenia wiąże się z podjęciem rzeczywistego działania ${ }^{72}$. Jak stwierdza ks. G. Strzelczyk, od strony teologii dogmatycznej: ,przebaczenie nie ma charakteru powszechnej amnestii aplikowanej automatycznie wszystkim grzesznikom. Może być skuteczne tylko wtedy, gdy spotka się z nawróceniem człowieka albo przynajmniej z uznaniem własnej grzeszności i niegodności"73. Jednakże w uzależnieniach behawioralnych życie sakramentalne nie może zastępować specjalistycznej terapii ${ }^{74}$, ale raczej wzmacnia ją aspektem nadprzyrodzoności. Niekiedy staje się pierwszą zachętą do korzystania z pomocy z zewnątrz ${ }^{75}$.

\section{Zakończenie}

Ludzka wolność potrzebuje przestrzeni rozwoju cnót teologicznych i moralnych. Jeśli w człowieku nie ma wzrostu, to następuje regres. Nasza wolność wymaga nieustannego treningu roztropności, sprawiedliwości, męstwa i umiarkowania. Im większa szlachetność cnót tym większa wolność. „Dzięki wolnej - przypomina Katechizm Kościoła Katolickiego - woli każdy decyduje o sobie. Wolność jest w człowieku siłą wzrastania i dojrzewania w prawdzie i dobru; osiąga ona swoją doskonałość, gdy jest ukierunkowana na Boga, który jest naszym szczęściem"76. Wolność jest sobą, kiedy wybiera dobro. Rozumna wolność harmonizuje uczucia popędliwe i gniewliwe, które zawierają w sobie element racjonalny, a który od strony duchowej i psychicznej może stać sprzymierzeńcem w walce nało-

72 Por. W. Stinissen, Spowiedź. Sakrament odpuszczania grzechów, W drodze, Poznań 2010, s. 37.

73 G. Strzelczyk, Teraz Jezus. Na tropach żywej chrystologii, Więź, Warszawa 2007, s. 77.

74 Sakrament spowiedzi powinien być systematyczny i nakierowywać na działanie łaski bożej. Dokonuje się rozeznanie między sferą ducha a psychiką. Rozgrzeszenie nie dotyczy emocji. Uczucia bycia niekochanym, bezwartościowym, osamotnienia nie znikają w chwili rozgrzeszenia. Przeżycie Miłosierdzia Bożego może pomóc w ich nazywaniu i przeżywaniu. Por. J. Prusak, Krzywdy w konfesjonale. Jak im zapobiegać? Jak leczyć?, w: Sztuka Spowiadania. Poradnik, red. J. Augustyn, WAM, Kraków 2017, s. 556.

75 Por. M. A. Fuentes, Rivestitevi di sentimenti di misericordia, s. 246.

76 KKK, n. 1731. 
gami. Siła destrukcyjna uzależnień pokazuje zmarnowaną szansę na wewnętrzne budowanie człowieka. Uzależnienia są konsekwencją szukania szczęścia na skróty. Przyjemność z kupowania czy z pracy nie sygnalizuje grzechu, ale przymus wewnętrzny może być znakiem ostrzegawczym. Pojawia się pytanie: czy zachowałem zdrowy umiar i kierowałem się zdrowym rozsądkiem? Uzależnienia od czynności czy zaburzenia od hazardu stanowią wyzwanie dla współczesnej psychoterapii: równowaga psychiczna człowieka, a także dla duchowości: powrót do modlitwy i sakramentów i dbałość o życie nadprzyrodzone. Znakiem przełomowym z punkty widzenia teologii moralnej - będzie wzbudzenie żalu za zło, wyrządzone sobie i innym ${ }^{77}$. Działania nałogowe mogą zmieniać kwalifikację czynu na grzech powszedni, ponieważ podmiot nie posiada aktualnie dobrowolności działania ${ }^{78}$, ale osoba ponosi konsekwencje uprzedniej decyzji związanej z wyborem zła moralnego. Nieodzowne jest podkreślanie łaski w życiu człowieka, zwłaszcza uwikłanego w uzależnienie. W przebiegu terapeutycznym odwołuje się często do „Siły wyższej”, ale teologia ją ukonkretnia: jest nią osoba Jezusa Chrystusa, który wyzwala z kręgu wszelkiego grzechu i usprawiedliwia przed Ojcem. Łaska Boga jest pierwotna w stosunku do decyzji walki z uzależnieniem. „Świętość [...]-zauważa teolog papieski, W. Giertych - to nie bezgrzeszność moralna, ale spotkanie ludzkiej słabości z mocą i miłością Bożą, którą się otrzymało w darze od Boga"79.

\section{Bibliografia}

Bartkowicz W., Wolność jako problem graniczny filozofii i teologii, Wydawnictwo Archidiecezji Warszawskiej, Warszawa 2004.

Blaszczynski A. - Nower L., A pathways model of problem and pathological gambling, w: „Addiction” 92/2002, s. 487-499.

Borowski A., Teologia moralna, t. I, KUL, Lublin 1960.

Cekiera Cz., Z badań nad etiologia i motywacja uzależnień (narkomania, lekomania, alkoholizm, nikotynizm), w: Problemy współczesnej psychologii, red. Z. Zalewski, Polskie Towarzystwo Psychologiczne, Lublin 1992, s. 587-591.

Franciszek, Amoris laetitia. Adhortacja apostolska o miłości w rodzinie (2016), Święty Paweł, Częstochowa 2016.

Franciszek, Evangelii gaudium. Adhortacja apostolska o głoszeniu Ewangelii w dzisiejszym świecie (2013), Wydawnictwo M, Kraków 2013.

77 Por. B. Häring, Nauka Chrystusa, 134.

78 KKK, n. 1735.

79 W. Giertych, Fides et passio, 39. 
Franciszek, Gaudete et exsultate. Adhortacja Apostolska o powołaniu do świętości w świecie współczesnym (2018), Wydawnictwo M, Kraków 2018.

Fuentes M. A., Rivestitevi di sentimenti di misericordia, Edivi, Roma 2014.

Gainsbury S.M., Online Gambling Addiction: the Relationship Between Internet Gambling and Disordered Gambling, w: „Current Addiction Reports” 2015, nr 2, s. 185-193.

Gałuszka T., Odnowa w tasce. Teologia charyzmatów św. Tomasza z Akwinu, Esprit, Kraków 2018.

Giertych W., Fides et passio, Bernardinum, Pelplin 2015.

Giertych W., Jak żyć łaską. Płodność Boża w czynach ludzkich, Bernardinum, Pelplin 2014.

Glombik K., Złożoność problemu odpowiedzialności w sytuacji uzależnienia czlowieka, w: Zniewoleni działaniem uzależnienia behawioralne a rodzina, red. P. Morciniec, Wydział Teologiczny Uniwersytetu Opolskiego, Opole 2013, s. 189-201.

Guerreschi C., Nowe uzależnienia, Wydawnictwo Salwator, Kraków 2006.

Häring B., Nauka Chrystusa. Teologia Moralna, t. I, Pallottium, Poznań 1962.

Katechizm Kościoła Katolickiego, Pallottinum, Poznań 2009.

Kokoszka A., Teologia moralna fundamentalna, Biblos, Tarnów 1998,

Kongregacja Nauki Wiary, Persona Humana. Deklaracja o niektórych zagadnieniach etyki seksualnej (1975), w: W trosce o życie. Wybrane Dokumenty Kościoła Stolicy Apostolskiej, red. K. Szczygieł, Biblos, Tarnów 1998, s. 319- 322.

Krok D., Uzależnienia behawioralne a zmiana jakości życia w perspektywie kontrowersji nad DSM-V, w: Zniewoleni działaniem uzależnienia behawioralne a rodzina, red. P. Morciniec, Wydział Teologiczny Uniwersytetu Opolskiego, Opole 2013, s. 9-26.

Ladaria L.F., Wprowadzenie do antropologii teologicznej, WAM, Kraków 1997.

Laird P., Wolność synowska, odpowiedzia w Duchu Świętym na Miłość Ojca, w: Synowie w Synu, teologia moralna fundamentalna, red. R. Tremblay, S. Zamboni, Promic, Warszawa 2009, 215-232.

Lo H. L.,Harvey N., Effects of shopping addiction on consumer decision-making: Web-based studies in real time, w: „Journal of Behavioral Addictions” 2012, nr 1, s. 162-70.

Mitoraj W., Zachowania o charakterze seksualnym, w: Zniewoleni działaniem uzależnienia behawioralne a rodzina, red. P. Morciniec, Wydział Teologiczny Uniwersytetu Opolskiego, Opole 2013, s. 65-76.

Nowakowski P.T., Uzależnienie od mediów, w: „Cywilizacja” 1009, nr 28, s. 149-157. 
Paweł VI, Encyklika Humanae Vitae (1968), w: W trosce o życie. Wybrane Dokumenty Kościoła Stolicy Apostolskiej, red. K. Szczygieł, Biblos, Tarnów 1998, s. 23-40.

Pinckaers S.T., Źródła moralności chrześcijańskiej, W drodze, Poznań 1994.

Prusak J., Krzywdy w konfesjonale. Jak im zapobiegać? Jak leczyć?, w: Sztuka Spowiadania. Poradnik, red. J. Augustyn, WAM, Kraków 2017, s. 541-558.

Rosso C., Garombo M., Sanzovo S., Contarino A., Furlan P.M., Il trattamento clinico degli aggressori sessuali: roflessione sulle criticitá e sugli obiettivi, w: Sessualita e dipendenze; dal desiderio alla violenza. Evoluzione e trattamento, red. F. Avenia - A. Pistuddi, FrancoAngeli, Milano 2012, s. 244-252.

Rowicka M., Uzależnienia behawioralne. Terapia i Profilaktyka, Fundacja Praesterno, Warszawa 2015.

Sperling A.P., Psychologia, Zysk i Sk-a, Poznań 1995.

Stinissen W., Spowiedź. Sakrament odpuszczania grzechów, W drodze, Poznań 2010.

Strzelczyk G., Teraz Jezus. Na tropach żywej chrystologii, Więź, Warszawa 2007. Suchy J., Pracoholik w rodzinie - korzyści czy zagrożenie?, w: Zniewoleni dziataniem uzależnienia behawioralne a rodzina, red. P. Morciniec, Wydział Teologiczny Uniwersytetu Opolskiego, Opole 2013, s. 131-145.

Tessore D., 7 grzechów głównych, Promic, Warszawa 2012.

Tischner J., Etyka solidarności, Znak, Kraków 2005.

Tomasz z Akwinu, Suma teologiczna, Veritas, Londyn 1963-1980.

Witek S., Duszpasterstwo w konfesjonale, Pallottinum, Poznań 1988.

Woroniecki J., Katolicka etyka wychowawcza, t. I, KUL, Lublin 1986.

Woronowicz T., Uzależnienia behawioralne, ze szczególnym uwzględnieniem patologicznego hazardu oraz uzależnienia od komputera i sieci, w: Zniewoleni działaniem uzależnienia behawioralne a rodzina, red. P. Morciniec, Wydział Teologiczny Uniwersytetu Opolskiego, Opole 2013, s. 27-53.

\section{Michal Cherubin: Behavioral addictions in the perspective of moral theology. Presentation and value}

\section{Summary}

Freedom of choice is being emphasized in highly developed societies. The problem is how to understand the ability of making a choice: can my choice lead to moral evil. Consumerism displays not only in dependences to psychoactive substances but also to behavioral addictions. One can get addicted to anything. That is why the important thing is to understand freedom which goes after one value-truth. The 
article presents freedom as a dynamic value which has to be gained and cultivated with moral virtues. If there is no moral development, there is vulnerability to all kinds of addictions. Further on, in the article there are examples of behavioral addictions, their genesis, stages and outcomes. Afterwards, the author undertakes judgment of behaviors in matter of the act and in the matter of the subject. In addition, there can be reduction of moral responsibility. Nonetheless, necessity of fighting with addiction is being emphasized.. The value of morally good life is accentuated in restored freedom in Christ.

Key words: freedom, behavioral addictions, dependences, moral virtues, moral responsibility 